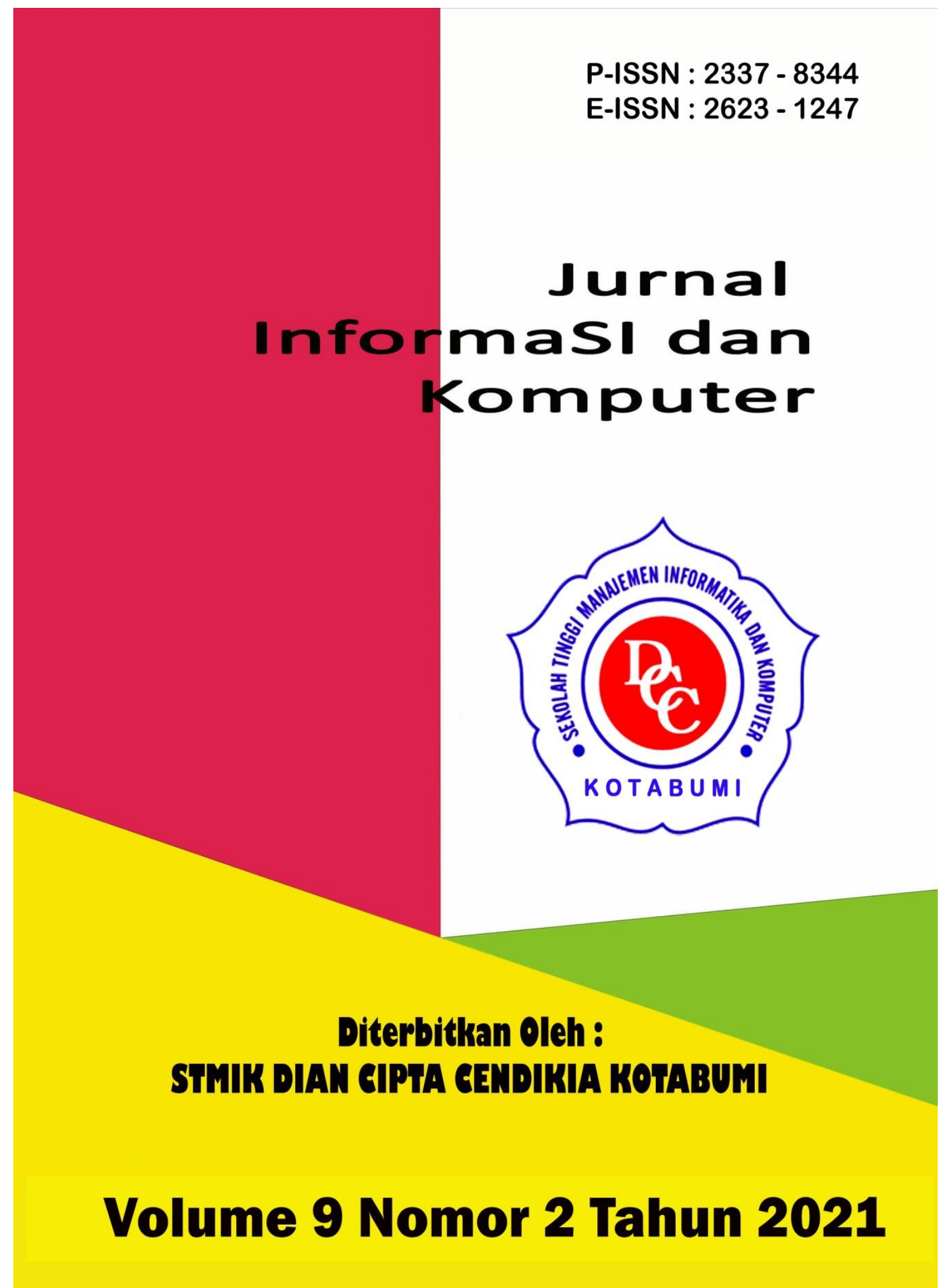




\section{Penerbit}

\section{Lembaga Penelitian STMIK Dian Cipta Cendikia Kotabumi}

Hak atas naskahh/tulisan tetap berada pada penulis, isi diluar tangung jawab penerbit dan Dewan Penyunting 


\section{PENGANTAR REDAKSI}

Puji syukur dipanjatkan kehadirat Tuhan Yang Maha Esa, atas karunia dan limpahan rahmatNYA jualah Jurnal Informasi dan komputer (JIK) STMIK Dian Cipta Cendikia Kotabumi ini dapat terwujud.Jurnal Informasi dan Komputer (JIK) yang terbit dua (2) kali dalam setahun ini merupakan suatu wadah untuk penyebar luasan hasil-hasil penelitian, studi pustaka, karya ilmiah yang berkaitan dengan Informasi dan Komputer khususnya bagi dosen-dosen STMIK Dian Cipta Cendikia Kotabumi serta umumnya para cendikiawan, praktisi, peneliti ilmu Informatika dan Komputer.

Harapan, dengan diterbitkannya Jurnal Informasi dan Komputer (JIK) ini sebagai salah satu bentuk sumbangan pemikiran dalam pengembangan ilmu informatika dan komputer yang berkaitan dengan kajian-kajian di bidang tekhnologi Informatik, Komunikasi Data dan Jaringan Komputer, perancangan dan Rekayasa Perangkat Lunak, serta ilmu-ilmu yang terkait dengan bidang Informasi dan Komputer lainnya.

Berkenaan dengan harapan tersebut, kepada para peneliti, dosen dan praktisi yang memiliki hasil-hasil penelitian, kajian pustaka, karya ilmiah dalam bidang tersebut diatas, dengan bangga redaksi Jurnal Informasi dan Komputer (JIK) menerima naskah ringkasan untuk dimuat pada jurnal Informasi dan Komputer (JIK) STMIK Dian Cipta Cendikia Kotabumi dengan berpedoman pada penulisan naskah jurnal sebagaimana dilampirkan pada halaman belakang (Bagian kulit dalam) buku jurnal ini.

Mutu dari suatu jurnal ilmiah tidak hanya ditentukan oleh para pengelolanya saja, tetapi para penulis dan pembaca jualah yang mempunyai peranan besar dalam meningkatkan mutu jurnal Informatika dan Komputer ini. Merujuk pada realita ini kamu sangat mengharapkan peran aktif dari peneliti untuk bersama-sama menjaga dan memelihara keberlangsungan dari jurnal Informasi dan Komputer STMIK Dian Cipta Cendikia Kotabumi ini. Yang juga tidak kalah pentingnya dari partisipasi tersebut diatas, adalah saran dan kritik yang membangun dari pembaca yang budiman agar kiranya dapat disampaikan langsung kepada redaksi JIK. Saran dan kritik yang membangun akan dijadikan masukan dan pertimbangan yang sangat berarti guna peningkatan mutu dan kualitas Jurnal Informasi dan Komputer STMIK Dian Cipta Cendikia Kotabumi.

Tak lupa diucapkan terima kasih yang tak terhingga atas perhatian dan kerjasama dari semua pihak yang tak dapat disebutkan satu persatu hingga dapat diterbitkan nya Jurnal Informasi dan Komputer (JIK) STMIK Dian Cipta Cendikia Kotabumi. Semoga apa yang telah diperbuat untuk kebaikan akan menjadi amal ibadah, amin.

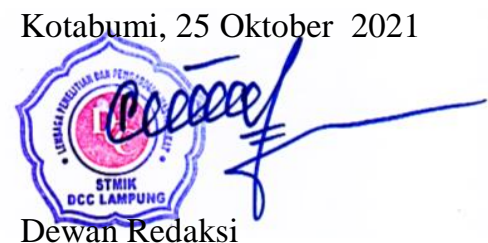




\section{JURNAL INFORMASI DAN KOMPUTER}

Volume 9 Nomor 2 Oktober 2021

Jurnal Informasi dan Komputer merupakan Sarana informasi ilmu pengetahuan, Tekhnologi dan Komunikasi yang berupa hasil penelitian, tulisan ilmiah, Ataupun studi pustaka. Jurnal ini terbit dua kali setahun pada bulan April dan Oktober. Berisi hasil penelitian ilmiah di bidang informatika yang bertujuan untuk menghubungkan adanya kesenjangan antar kemajuan teknologi dan hasil penelitian. Jurnal ini di terbitkan pertama kali pada tahun 2013.

Penanggung Jawab:

Ketua STMIK Dian Cipta Cendikia Kotabumi

\section{Pembina:}

Ketua STMIK Dian Cipta Cendikia Kotabumi Ketua Lembaga Penelitian STMIK Dian Cipta Cendikia Kotabumi

\section{Pimpinan Redaksi}

Dwi Marisa Efendi,.S.Kom.,M.Ti

\section{Redaksi pelaksana}

Rustam,.S.Kom,.M.Ti (STMIK Dian Cipta Cendikia Kotabumi)

Nurmayanti M.Kom (STMIK Dian Cipta Cendikia Kotabumi)

Sukatmi,.S.Kom., M.Kom (AMIK DCC Bandar Lampung)

Sampurna Dadi Riskiono,M.Kom (Universitas Teknokrat Indonesia)

Ifo Wahyu Pratama,S.Kom.,M.Ti(AMIK MASTER Lampung)

\section{Mitra Bestari}

Dr. RZ. ABDUL AZIZ, ST., MT (Institut Informatika dan Bisnis Darmajaya)

Dr. Dadang Sudrajat, S.Si, M.Kom (STMIK IKMI Cirebon)

Dr. Septafiansyah Dwi Putra, S.T., M.T (Politeknik Negeri Lampung)

Dr. Evi Grativiani, S.E., M.S.I (Universitas Sebelas Maret)

Rohmat Indra Borman ( Universitas Teknokrat Indonesia )

Ferry Wongso, S.KOm., M.Kom ( STMIK Darma Pala Riau)

Ferly Ardhy, S.Kom., M.Ti ( Universitas Aisyah Pringsewu )

Firmansyah, S.E., M.Si (STMIK Darma Pala Riau)
Amarudin (Universitas Teknokrat Indonesia)

Didi Susianto, S.T., M.Kom (AMIK Dian Cipta Cendika Bandar Lampung)

Alhibarsyah, St., M.Kom (STMIK Tunas

Bangsa Bandar Lampung)

Kemal Farouq Mauladi, S.Kom .M.Kom (Universitas Islam Lamongan)

Rima Mawarni, M.Kom ( STMIK Dian Cipta Cendikia Kotabumi)

Wira Jaya Hartono, S.Pd., M.Pd ( STMIK Darma Pala Riau)

Penerbit : STMIK Dian Cipta Cendikia Kotabumi Bekerja Sama Dengan LPPM STMIK Dian Cipta Cendikia Kotabumi.

\section{Alamat Redaksi/Penerbit:}

Jl. Negara No. 3 Candimas Kotabumi Lampung Utara

No Telpon/Fax 072423003

Email : 1ppm-stmik@dcc.ac.id 


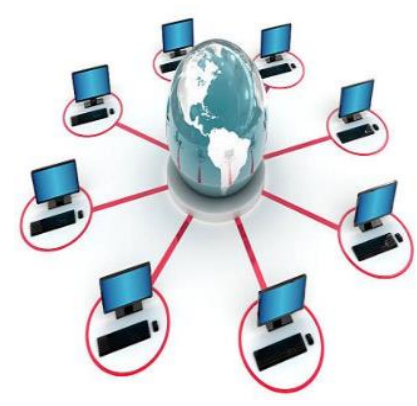

\section{JURNAL INFORMASI DAN KOMPUTER VOL. 9 NO. 2 THN. 2021}

\section{DAFTAR ISI}

Halaman

Sistem Informasi Akuntansi Persedian Barang Berbasis Web Pada Lembaga

Permasyarakatan Kelas II A Banceuy Bandung : "Kelompok Tani Desa Banjar Kertarahayu" Teuku Rian Hardiyansyah, Fatia Salsa Azzahra (Politeknik Piksi Ganesha Bandung ${ }^{1,2}$ ).....

Penerapan Finite State Automata Pada Vending Machine Penjual Obat Non Resep

Dokter Dan Keperluan Medis

Eko Supriyanto $^{1}$, Angga Ardiansyah ${ }^{2}$, Frieyadie $^{3}$, Sri Rahayu ${ }^{4}$, Windu Gata ${ }^{5}$

(Universitas Nusa Mandiri ${ }^{12}$ ) $08-14$

Sistem Pendukung Keputusan Untuk Menentukan Kelayakan Pengajuan Sertifikasi Guru Dengan Metode Simple Additive Weighting (Studi Kasus : Ma Al Muhajirin Janti Jogoroto Jombang)

Budiman, umam baharudin, winarti

(Universitas Darul 'Ulum Jombang)

Perancangan Infrastruktur Domain Name Server Lokal Menggunakan Ubuntu Server 16.04

Pada PT. Xyz

Zaenal Mutaqin Subekti, Hendra Setiawan, Satria, Widia Murni Wijaya,

Aliy Hafiz, Warsudi

(STMIK Bani Saleh, Universitas Negeri Yogyakarta, AMIK Dian Cipta Cendikia,

STMIK MIC CIkarang)

Perancangan Sistem Informasi Idea Proposal (Ip) Berbasis Web Pada Pt. Paxel Algorita Unggul

Julian Murhan Sahputra, Indah Purnamasari

(Universitas Nusa Mandiri ${ }^{12}$ )

Sistem Pendukung Keputusan Untuk Menentukan Ekstrakurikuler Atletik

Berdasarkan Bakat Siswa Menggunakan Metode Profile Matching

Agnes Basuki, Petrus Sokibi, Tiara Eka Putri

(Universitas Catur Insan Cendekia)

Penerapan Algoritma K-Means Untuk Pengelompokan Usia Calon Penerima Vaksin

Di Kab. Ngawi

Irna Yuniarfi, Saifulloh

(Universitas PGRI Madiun ${ }^{12}$ )

System Penilaian Seleksi Calon Karyawan Baru Menggunakan Metode Simple Additive Weighting (SAW) Di PT.TNA

Anik Sri Wahyuningsih, Yudhi Firmansyah

(Universitas Panca Sakti Bekasi )

Perancangan Sistem Informasi Pembayaran SPP Menggunakan Framework Laravel 
Ichwan Habib Moudi

(Universitas Panca Sakti Bekasi) $75-80$

Implementasi Algoritma K-Means Dan Algoritma Apriori Optimasi Kinerja Ecu

(Study Kasus Mobil Avanza Dan Xenia)

Sigit Mintoro' Asep Afandi

(STMIK Dian Cipta Cendikia Kotabumi)

Sistem Pakar Penyakit Buah Kakao Untuk Peningkatan Hasil Panen Kakao Menggunakan

Metode Case Base Reasoning (CBR) Berbasis Web Mobile

Aliy hafiz, Verawati

(AMIK Dian Cipta Cendikia,Bandar Lampung)

Penerapan Metode Rapid Application Develomment (RAD) Dalam Pengembangan

Sistem Pemesanan Menu Berbasis Android

Aris Baihaqi, Tumini

(Fakultas Sains dan Teknologi ${ }^{1,2}$ )

Rancang Bangun Sistem Informasi Geografis Pariwisata Di Lampung Timur

Sukatmi, Rexa Alfa Rizi

(AMIK DCC Bandar Lampung ${ }^{12}$ )

Implementasi Psak No. 45 Pada Proses Penyusunan Laporan Keuangan Menggunakan

M.S. Excel Dan Aplikasi Accurate Accouting Pada STMIK Bani Saleh

Marhakim, Willy Adam

(STMIK Bani Saleh ${ }^{12}$ )

Sistem Prediksi Harga KOPI LAMBAR ( Lampung Barat) Dengan Metode

Backpropagation, dan Double Exponential ( Studi Kasus BUMDES )

Supriyanto, Dwi marisa Efendi,Rhomadhon

(STMIK Dian Cipta cendikia Kotabumi ${ }^{1-}$ )

Sistem Informasi Pemasaran Produk Umkm Berbasis Web Pada Kecamatan Bumi

Nabung Lampung Tengah

Yuli Syafitri, Agus Prasetyo, Reni Astika

(AMIK Dian Cipta Cendikia Bandar Lampung)

Rancang Bangun Aplikasi Pembelajaran Aksara Lampung Berbasis Android

Ferly Ardhy, Hendra Syahrobi

(Universitas Aisyah Pringewu ${ }^{1,}$ STMIK Dian Cipta Cendikia ${ }^{2}$ )

Sistem Pakar Diagnosa Penyakit Kulit Pada Balita Menggunakan Metode Naïve

Bayes Dan Forward Chaining Studi Kasus Puskesmas Cempaka Sungkai Selatan

Sidik Rahmatullah, Rima Mawarni

(STMIK Dian Cipta Cendikia Kotabumi ${ }^{12}$ )

Rekayasa Perangkat Lunak Perhitungan Harga Pokok Produksi Metode

Full Costing Pada Umkm Mitra Cake Di Bandar Lampung

Pitrawati, Arif Sanjaya

(AMIK Dian Cipta Cendikia, Bandar Lampung)

Rancang Bangun Sistem Ujian Online Menggunakan Algoritma Cosine Similarity

Berbasis Web

Haryono, Zaenal Mutaqin Subekti, Widiyawati, Hidayatullah

(STMIK Bani Saleh ${ }^{1234}$ )

$163-168$ 
Model Aplikasi Helpdesk Ticketing System Berbasis Web Menggunakan Metode Rad Indra Permana

Pattern Recognition Tulisan Tangan Huruf Hijaiyah Menggunakan Metode Convolutional Neural Network (CNN)

Mufassiril Abror, Nopiyanto

(Universitas Panca Sakti Bekasi ${ }^{12}$ )

Aplikasi Sistem Informasi Keuangan Berbasis Android Di Perumahan Taman

Karang Bahagia

Melda Ayulestari

(Universitas Panca Sakti Bekasi)

Audit Pelayanan Sistem Rujukan Online Puskesmas Menggunakan Framework COBIT 5.0

Nurmayanti, Merri Parida, Ngajiyanto, Ina Anzalna

(STMIK Dian Cipta Cendikia Kotabumi ${ }^{1234}$ )

Perancangan Sistem Informasi Pengolahan Data Nilai Siswa Berbasis Web

Erin Ermawati, Anik Sri Wahyuningsih

(Fakultas Sain dan Teknologi, Universitas Panca Sakti Bekasi ${ }^{12}$ )

Pengembangan Sistem Pelaporan Data Hasil Inspeksi Barang Berbasis Web

Siska Putriani

(Universitas Pancasakti Bekasi)

Penerapan Extreme Programming Dalam Perancangan Aplikasi Web Food Market

Tumini, Hilman Septiana

(Fakultas Sains dan Teknologi Universitas Panca Sakti Bekasi ${ }^{1,2}$ )

Sistem Pencarian Barang Berbasis Website Menggunakan Php Dan Mysql

Studi Kasus PT. Surya Technology Industri

Sulaeman

(Universitas Panca Sakti Bekasi)

Implementasi Metode Prototype Pada Sistem Peminjaman Alat Kerja Berbasis Web

Di PT SK Metalindo

Ali Mulyanto, Arjun Gunawan

(Univeritas Panca Sakti Bekasi)

Aplikasi Tata Cara Wudhu Menggunakan Teknologi Augmented Reality

Sebagai Media Pembelajaran

Di TK Al Fatih

Ahmad Yakub, Idarul Fadli

(Universitas Panca Sakti Bekasi ${ }^{12}$ )

Sistem Pakar Diagnosa Penyakit Ayam Petelur Menggunakan Metode Certainty Factor

Berbasis Web

Mochammad Taufiq Hidayat, Ali Mulyanto

(Universitas Panca Sakti Bekasi ${ }^{12}$ )

Penerapan Metode Prototyping Dalam Perhitungan Hasil Produksi Menggunakan

Arduino Uno R3 Dan Php Di PT. Indonesia Epson Industry

Amandha Aulia, Ajar Rohmanu

(Universitas Panca Sakti Bekasi ${ }^{12}$ )

$156-164$ 
System Pendukung Keputusan Penentuan Guru Teladan Dengan Metode Profile Matching Hasbulloh, Agmawarnida (Universitas Panca Sakti Bekasi ${ }^{1,2}$ )

Implementasi Waterfall Method Pada Aplikasi Buku Induk Siswa Berbasis Web Idam Holid, Yogie Krisnayadi (Universitas Panca Sakti ${ }^{12}$ )

Pengembangan Text To Speech Media Pembelajaran Untuk Pengenalan

Anggota Tubuh Manusia Kelas V Sekolah Dasar

Juwanda Saputra, Ali Mulianto

(Teknik Infomratika Fakulutas Sains dan Teknologi ${ }^{12}$ )

Perancangan Sistem Peminjaman Barang Berupa Aset Tetap Berbasis Web

Pada Lembaga Permasyarakatan Kelas II A Banceuy Bandung

Guntur Salasa Priambodo, Perwito, Candra Mecca Sufyana

(Politeknik Piksi Ganesha Bandung ${ }^{1,2,3}$ )

Metode Pemilihan Karyawan Terbaik Sebagai Penentu Goodwill Perguruan Tinggi

Dengan Menggunakan Metode Topsis (Studi Kasus Perguruan Tinggi Di Lampung Utara)

Dwi Sartika, Pakarti Riswanto

(STMIK Dian Cipta Cendikia Kotabumi)

Sistem Pendukung Keputusan Pemilihan Merek Smartphone Menggunakan

Metode Analytical Hierarchy Process (AHP)

Ade Kiki Fatmawati, Muhammad Sultan Raflie, Norma Yunita

(Universitas Nusa Mandiri ${ }^{123}$ )

Pattern Recognition Aksara Lampung Menggunakan Algoritma Neural Network

Metode Analytical Hierarchy Process (AHP)

Nopiyanto, Rahmadi

(Universitas Panca Sakti Bekasi) 116-121 


\title{
PERANCANGAN SISTEM INFORMASI PENGOLAHAN DATA NILAI SISWA BERBASIS WEB
}

\author{
Erin Ermawati ${ }^{1}$, Anik Sri Wahyuningsih ${ }^{2}$ \\ Fakultas Sain dan Teknologi, Universitas Panca Sakti Bekasi ${ }^{12}$ \\ Jl. Kapten Sumantri No.16, Cikarang Utara, Bekasi, Jawa Barat 17530 \\ Email : erinerma23@gmail.com ${ }^{1}$, anikstmik@gmail.com ${ }^{2}$
}

\begin{abstract}
ABSTRAK
Perkembangan teknologi saat ini semakin pesat sehingga seluruh dunia dalam berbagai bidang harus mengikuti perkembangan yang pesat pada sat ini. Pendidikan merupakan awal dari pembentukan karakter dan jiwa manusia untuk dapat belajar untuk bekal dimasa depan oleh karena itu sistem teknologi harus di terapkan pada sekolah dari berbagai tingkatan. Perancangan sistem informasi pengolahan data nilai Siswa berbasis web merupakan suatu sistem yang memberikan data yang di olah oleh guru dan admin sekolah, Permasalahan yang terjadi saat ini yang terjadi dalam pengolahan nilai untuk rapot siswa yang ada di Sekolah Taman Kanak (TK) Kiddy ABC Islamic School yang berada di Perumahan Gramapuri Persada, F4/B RT/RW.002/007, Kel.Sukajaya, Kec.Cibitung, Kab.Bekasi, Jawa Barat. Saat ini pengolah data masih manual menggunakan microsoft excel di dalam komputer sehingga tidak cepat terkoneksi dengan guru-guru lainya dan kepala sekolah. Penelitian ini bertujuan untuk mempermudah para guru atau admin sekolah yang bertugas dalam mengolah data siswa dalam hal input data, mengolah data dan output data nilai siswa untuk dipergunakan dalam raport siswa. Apikasi ini menggunakan bahasa pemrograman PHP dan MysQ1 sebagai databasenya XAMPP sebagai web server untuk perancangan sistem.Sistem ini bekerja memasukan dan menyimpan data, proses penilaian siswa serta laporan nilai akhir siswa sehingga lebih mudah mengetahui informasi nilai siswa yang akan disampaikan oleh pihak sekolah.Penelitian telah menghasilkan sebuah sistem pengolahan nilai yang membantu kerja dari administrasi dan wali kelas dan dapat mempermudah pengguna untuk melakukan proses pengolahan nilai agar pengelolaan nilai dapat diolah lebih efisien dan efektif.
\end{abstract}

Kata Kunci : Sistem Informasi, Data Nilai, Web, Php, XAMPP, Mysql

\section{ABSTRACTS}

The development of technology is currently growing rapidly so that the whole world in various fields must follow the rapid developments at this time. Education is the beginning of the formation of character and the human soul to be able to learn for the provision of the future, therefore technology systems must be applied to schools from various levels. The design of a web-based student value data processing information system is a system that provides data that is processed by teachers and school admins, the current problems that occur in processing grades for student report cards in Kiddy ABC Islamic School Kindergarten (TK) which is in the Gramapuri Persada Housing, F4/B RT/RW.002/007, Kel. Sukajaya, Kec. Cibitung, Kab. Bekasi, West Java. Currently the data processing is still manual using Microsoft Excel on the computer so it is not quickly connected with other teachers and school principals. This study aims to make it easier for teachers or school admins in charge of processing student data in terms of data input, data processing and student value data output to be used in student report cards. This application uses the PHP and MySQL programming languages as the database XAMPP as a web server for system design. This system works to enter and store data, student assessment processes and student final grade reports so that it is easier to find out student grade information that will be submitted by the school. Research has produce a value processing system that helps the work of administration and homeroom teachers and can make it easier for users to process values so that value management can be processed more efficiently and effectively.

Keywords: Information System, Value Data, Web, Php, XAMPP, Mysql 


\section{PENDAHULUAN}

Perancangan sistem informasi pengolahan data nilai Siswa berbasis web merupakan suatu sistem yang memberikan data yang di olah oleh guru dan admin sekolah, Permasalahan yang terjadi saat ini yang terjadi dalam pengolahan nilai untuk rapot siswa yang ada di Sekolah Taman Kanak (TK) Kiddy ABC Islamic School yang berada di Perumahan Gramapuri Persada, F4/B RT/RW.002/007, Kel.Sukajaya, Kec.Cibitung, Kab.Bekasi, Jawa Barat. Saat ini pengolah data masih manual menggunakan microsoft excel di dalam komputer sehingga tidak cepat terkoneksi dengan guru-guru lainya dan kepala sekolah. Penelitian ini bertujuan untuk mempermudah para guru atau admin sekolah yang bertugas dalam mengolah data siswa dalam hal input data, mengolah data dan output data nilai siswa untuk dipergunakan dalam raport siswa. Apikasi ini menggunakan bahasa pemrograman PHP dan MysQl sebagai databasenya XAMPP sebagai web server untuk perancangan sistem.Sistem ini bekerja memasukan dan menyimpan data, proses penilaian siswa serta laporan nilai akhir siswa sehingga lebih mudah mengetahui informasi nilai siswa yang akan disampaikan oleh pihak sekolah.Penelitian telah menghasilkan sebuah sistem pengolahan nilai yang membantu kerja dari administrasi dan wali kelas dan dapat mempermudah pengguna untuk melakukan proses pengolahan nilai agar pengelolaan nilai dapat diolah lebih efisien dan efektif.

\section{TINJAUAN PUSTAKA}

\subsection{Perancangan Sistem}

Perancangan sistem adalah penentuan proses dan data yang diperlukan oleh sistem baru. Tujuan dari perancangan sistem adalah untuk memenuhi kebutuhan pemakai sistem serta untuk memberikan gambaran yang jelas dan rancang bangun yang lengkap. [1].

\subsection{Sistem Informasi}

sistem informasi adalah rangkaian prosedur formal dimana data dikumpulkan, diproses menjadi informasi dan didistribusikan kepada pemakai [2].

\subsection{Pengolahan Data}

Data menggambarkan suatu kejadian yang sedang terjadi, dimana data tersebut akan diolah dan diterapkan dalam sistem menjadi input yang berguna bagi suatu sistem [3].

\subsection{Nilai Siswa}

Nilai merupakan ekspresi dari konsep- konsep yang merepresentasikan sekumpulan energy yang dinamis. Menurut Kamus Besar Bahasa Indonesia nilai merupakan sesuatu yang menyempurnakan manusia sesuai dengan hakikatnya [4]

\subsection{Website}

Website adalah halaman informasi yang disediakan melalui jalur internet sehingga bias diakses di seluruh dunia selama terkoneksi dengan jaringan internet [5].

\subsection{Hypertext Preprocessor (PHP)}

PHP Hypertext Preprocessor adalah suatu bahasa pemrograman yang digunakan untuk menterjemahkan basis kode program menjadi kode mesin yang dapat dimengerti oleh komputer yang bersifat server-side yang ditambahkan ke HTML [6].

\subsection{Basis Data}

Basis data (database) adalah kumpulan suatu informasi yang disimpan didalam komputer secara sistematik dimana suatu informasi tersebut dapat diperiksa menggunakan suatu program komputer untuk memperoleh informasi [7].

\subsection{Pengujian Sistem Black Box}

Menurut Khan dan Khan (2014:3), "Pengujian sistem berkembang seiring dengan berkembangnya metode pengembangan sistem dan teknologi aplikasi yang dibangunnya. Tahapan pengujian selalu ada dalam salah satu tahapan pengembangan sistem yang ada. Pengujian sistem menjadi penting karena hanya melewati tahap yang mampu menunjukkan kesiapan sistem sebelum diterapkan di lapangan. Pengujian perangkat lunak memiliki peranan penting dalam siklus hidup, sistem untuk mendeteksi tingkat kesulitan yang ada dalam tiap proses dengan baik [8].

Blackbox testing yaitu menguji perangkat lunak dari segi spesifikasi fungsional tanpa menguji 
desain dan kode program[9].

\section{METODE PENELITIAN}

\subsection{Waterfall}

Metode Waterfall adalah salah satu model dalam pengembangan sistem Rekayasa Perangkat Lunak dimana klien dan pengembang dapat saling berkomunikasi dalam memenuhi kebutuhan sistem [8].

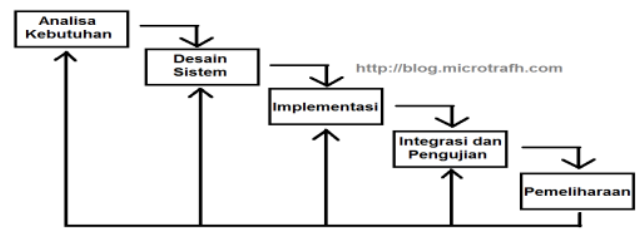

Gambar 3.1 Waterfall

\subsection{Tahapan Metode Penelitian}

\subsubsection{Analisa Sistem Kebutuhan}

Pada tahap ini objek penelitian di TK Kiddy ABC Islamic School yang berada di Perumahan Gramapuri Persada, F4/B RT/RW.002/007, Kel.Sukajaya, Kec.Cibitung, Kab.Bekasi, Jawa Barat. Dengan wawancara pada pihak terkait mengenai masalah dan kebutuhan kemudia di ambil kesimpulan.

Selain itu Agar sebuah sistem dapat berjalan dengan baik maka harus memiliki kemampuan yang memadai diantaranya yaitu:

\section{a. Kebutuhan Perangkat Keras}

1) PC ( personal komputer )

2). Prosessor Intel Core 2 Quad 2,4 GHz

3) $\operatorname{Ram} 2 \mathrm{~Gb}$

4) HDD $320 \mathrm{~Gb}$

5) Monitor

\section{b. Kebutuhan Perangkat Lunak}

Perangkat lunak yang digunakan mendukung dalam pembuatan dan pengoperasian program aplikasi ini adalah sebagai berikut:

1. Operasi Sistem Windows versi 7,8 dan seterusnya

2. Memiliki Xampp

3. Desain Sistem Desain sistem ini di buat dari hasil analisa terhadap sekolah TK Kiddy ABC Islamic School di permahan gramapuri persada, dan aplikasi ini di rancang sesuai dengan kebutuhan sekolah yang berfokus kepada penilaian terhadap siswa-siswa yang di ubah menjadi terkomputerisasi dengan 1 sistem. Aplikasi sistem ini desain dengan Use Case Diagram, Activity Diagram, Sequence Diagram, Class Diagran dan aplikasi dibuat menggunakan bahasa pemrograman $\mathrm{Php}$, serta menggunakan database MySql.

\subsubsection{Use Case Diagram Sistem Usulan}

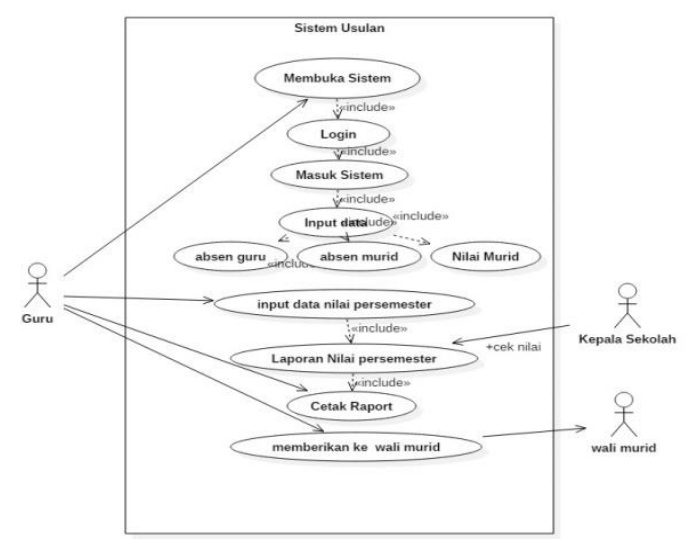

Gambar 3.2 Use Case Diagram Sistem Usulan

\subsubsection{Activity Diagram}

a. Login

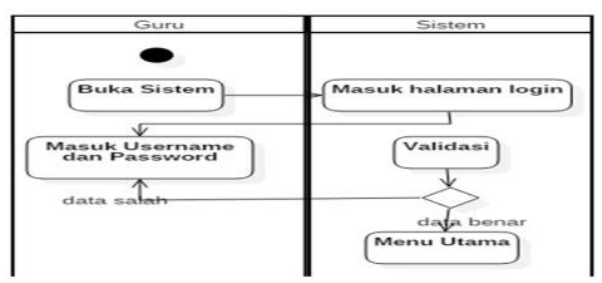

Gambar 3.3 Activity Diagram Login

b Proses Input Nilai

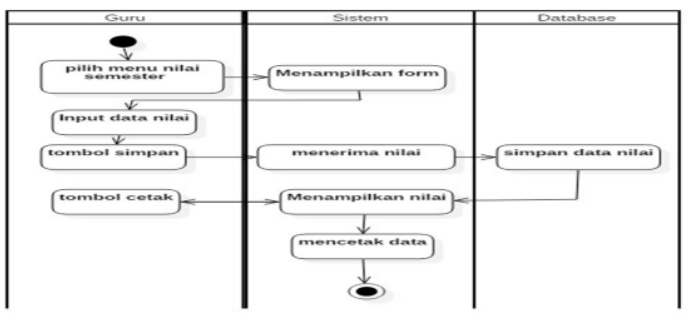


Gambar 3.4 Activity Diagram Input Nilai

\subsubsection{Sequence Diagram}

\section{a. Login}

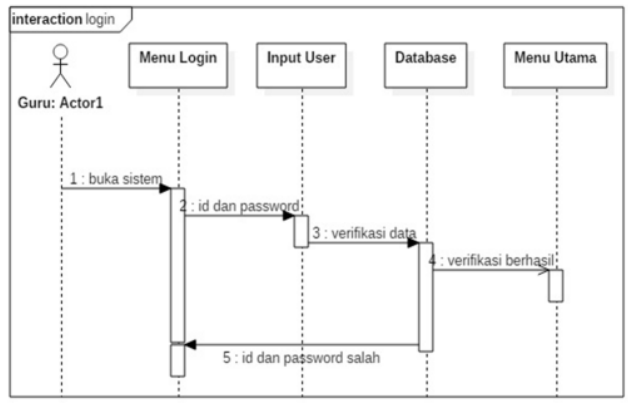

Gambar 3.5 Sequencse Diagram Login

\subsubsection{Proses Input Nilai}

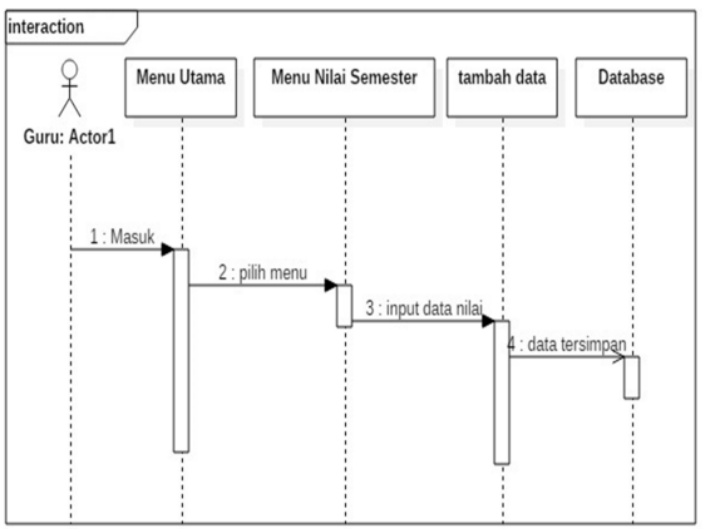

Gambar 3.6 Sequence Diagram Input Nilai

\subsubsection{Proses Cetak Raport}

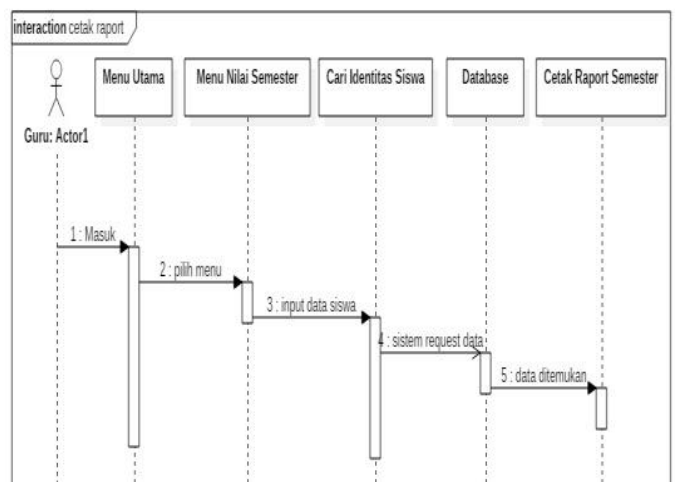

Gambar 3.7 Sequence Diagram Cetak Raport

\subsubsection{Class Diagram}

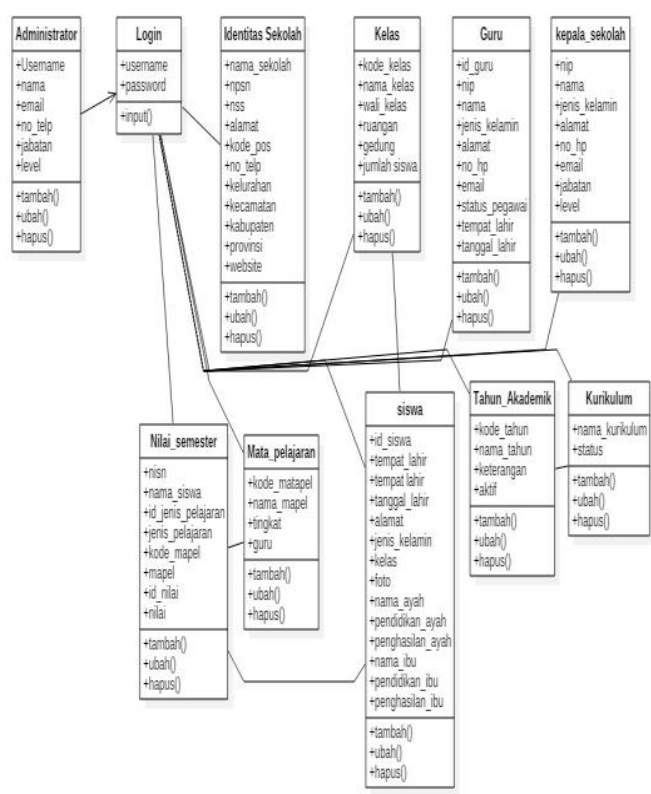

Gambar 3.8 Class Diagram Sistem Usulan

\subsection{Implementasi}

Aplikasi sistem ini di implementasikan berbasis web dengan tampilan-tampilan yang menarik yang diperuntukkan untuk para guru dan staffstaff Sekolah TK Kiddy ABC Islamic School. Implementasi sistem adalah sistem yang di buat dan telah jadi sesai dengan apa yang dibutuhkan dan di rancang . hasil sistem yang dibuat akan di tampilkan pada bab 3 di hasi dan pembahasan.

\subsection{Integrasi dan Pengujian}

Pada tahap ini pengujian sistem dilakukan dengan metode pengujian sistem black box adapun di antar pengujian yang dilakukan adalah sebagai berikut.

\section{a. Rancangan Pengujian}

Tabel 3. 1 Rancangan Pengujian 


\begin{tabular}{|l|l|l|l|}
\hline No. & $\begin{array}{l}\text { Kelas } \\
\text { Uji }\end{array}$ & $\begin{array}{l}\text { Detail } \\
\text { Pengujian }\end{array}$ & $\begin{array}{l}\text { Jenis } \\
\text { Pengujian }\end{array}$ \\
\hline 1 & $\begin{array}{l}\text { Menu } \\
\text { Login }\end{array}$ & $\begin{array}{l}\text { Verifikasi data } \\
\text { Login dan Hak } \\
\text { Akses Login }\end{array}$ & $\begin{array}{l}\text { Black } \\
\text { Box }\end{array}$ \\
\hline 2 & $\begin{array}{l}\text { Menu } \\
\text { admin }\end{array}$ & $\begin{array}{l}\text { Proses } \\
\text { menampilkan } \\
\text { data, fungsi } \\
\text { tombol dan } \\
\text { input data }\end{array}$ & $\begin{array}{l}\text { Black } \\
\text { Box }\end{array}$ \\
\hline 3 & $\begin{array}{l}\text { Menu } \\
\text { Nilai }\end{array}$ & $\begin{array}{l}\text { Menampilkan } \\
\text { input dan } \\
\text { output nilai }\end{array}$ & $\begin{array}{l}\text { black } \\
\text { Box }\end{array}$ \\
\hline
\end{tabular}

Tabel 3.2 Tabel Pengujian Login

\begin{tabular}{|c|c|c|c|c|}
\hline No & Skenario & Bagian di Uji & $\begin{array}{l}\text { Prosedur } \\
\text { Pengujian }\end{array}$ & $\begin{array}{l}\text { Hasil } \\
\text { Pengujian }\end{array}$ \\
\hline 1 & $\begin{array}{c}\text { username dan } \\
\text { password tidak } \\
\text { di isi }\end{array}$ & $\begin{array}{c}\text { user name dan } \\
\text { password tidak diisi }\end{array}$ & \begin{tabular}{|c|} 
Sistem \\
tidak \\
Menerima \\
login \\
dengan \\
password \\
kosong \\
\end{tabular} & Berhasil \\
\hline 2 & $\begin{array}{l}\text { username dan } \\
\text { password di isi }\end{array}$ & $\begin{array}{l}\text { username : admin } \\
\text { pass word : admin }\end{array}$ & \begin{tabular}{|c|} 
sistem \\
menerima \\
pasword \\
dan \\
username \\
yang telah \\
terdaftar
\end{tabular} & Berhasil \\
\hline
\end{tabular}

Tabel 3.4Tabel Menu Administrator

\begin{tabular}{|c|l|l|l|l|}
\hline N & $\begin{array}{l}\text { Sekena } \\
\text { rio }\end{array}$ & $\begin{array}{l}\text { Test } \\
\text { Case }\end{array}$ & Hasil & $\begin{array}{l}\text { Kesim } \\
\text { pulan }\end{array}$ \\
\hline 1 & $\begin{array}{l}\text { Tombo } \\
1 \quad \text { dari } \\
\text { menu } \\
\text { utama }\end{array}$ & $\begin{array}{l}\text { klik } \\
\text { tombol } \\
\text { data } \\
\text { master, } \\
\text { data } \\
\text { penggu } \\
\text { na,data } \\
\text { akadem } \\
\text { ik, data } \\
\text { absensi }\end{array}$ & $\begin{array}{l}\text { Terbuka } \\
\text { menampil } \\
\text { kan data } \\
\text { yang } \\
\text { tertera di } \\
\text { database } \\
\text { masing- } \\
\text { masing } \\
\text { dan juga } \\
\text { menampil } \\
\text { kan } \\
\text { laporan } \\
\text { nilai } \\
\text { siswa } \\
\text { tombol- } \\
\text { tombol } \\
\text { tambah,ub } \\
\text { ah dan } \\
\text { hapus }\end{array}$ & \\
& & \\
& & \\
\end{tabular}

\begin{tabular}{|c|c|c|c|c|}
\hline 2 & $\begin{array}{l}\text { Tombo } \\
1 \\
\text { tambah } \\
\text {, ubah } \\
\text { dan } \\
\text { hapus }\end{array}$ & $\begin{array}{l}\text { klik } \\
\text { tambah } \\
, \text { ubah } \\
\text { dan } \\
\text { hapus } \\
\text { pada } \\
\text { setiap } \\
\text { menu }\end{array}$ & $\begin{array}{l}\text { Menampil } \\
\text { kan form } \\
\text { tambah, } \\
\text { ubah dan } \\
\text { akan } \\
\text { terhapus } \\
\text { jika di } \\
\text { klik hapus }\end{array}$ & $\begin{array}{l}\text { Berha } \\
\text { sil }\end{array}$ \\
\hline 3 & $\begin{array}{l}\text { tombo } \\
1 \\
\text { simpa } \\
\text { n dan } \\
\text { batal }\end{array}$ & $\begin{array}{l}\text { klik } \\
\text { tombo } \\
1 \\
\text { simpa } \\
\text { n dan } \\
\text { batal } \\
\text { pada } \\
\text { setiap } \\
\text { tamba } \\
\text { h } \\
\text { data }\end{array}$ & $\begin{array}{l}\text { Data } \\
\text { tersimpa } \\
\text { n dan } \\
\text { akan } \\
\text { kembali } \\
\text { ke menu } \\
\text { sebelum } \\
\text { nya jika } \\
\text { klik } \\
\text { batal }\end{array}$ & $\begin{array}{l}\text { Berh } \\
\text { asil }\end{array}$ \\
\hline
\end{tabular}

Tabel 3.3 Pencarian Data

\begin{tabular}{|l|l|l|l|l|}
\hline No & $\begin{array}{l}\text { Seken } \\
\text { ario }\end{array}$ & $\begin{array}{l}\text { Test } \\
\text { Case }\end{array}$ & Hasil & $\begin{array}{l}\text { Kesim } \\
\text { pulan }\end{array}$ \\
\hline 1 & $\begin{array}{l}\text { Data } \\
\text { Nilai } \\
\text { Semes } \\
\text { ter }\end{array}$ & $\begin{array}{l}\text { Isi } \\
\text { data } \\
\text { Nilai } \\
\text { dari } \\
\text { salah } \\
\text { satu } \\
\text { siswa }\end{array}$ & $\begin{array}{l}\text { Nilai } \\
\text { Tersimp } \\
\text { an }\end{array}$ & $\begin{array}{l}\text { Berhas } \\
\text { i }\end{array}$ \\
& & $\begin{array}{l}\text { Klik } \\
\text { nama } \\
\text { siswa } \\
\text { yang } \\
\text { telah } \\
\text { diisi } \\
\text { nilai }\end{array}$ & $\begin{array}{l}\text { Menamp } \\
\text { ilkan } \\
\text { nilai } \\
\text { keseluru } \\
\text { han }\end{array}$ & Berhas \\
& Rap & \\
& Raport & \\
& & & \\
\end{tabular}

\subsection{Pemeliharaan Sistem}

Pemeliharaan sistem dilakukan cek fungsi pada setiap waktunya dan akan diperbaiki ketika ada masalah dalam tampilan maupun eror pada kode sistem tersebut.

\section{HASIL DAN PEMBAHASAN}

Hasil dan pembahasan akan akan menampilkan gambar berupas sistem yang dibuat.

\subsection{Aplikasi Sistem}




\subsubsection{Tampilan Aplikasi Sistem}

\section{a. Login}

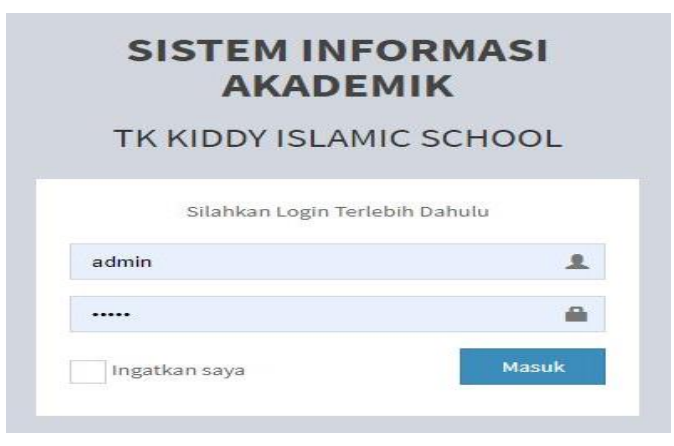

Gambar 4.1.1 login

\section{b. Tampilan Menu Utama}

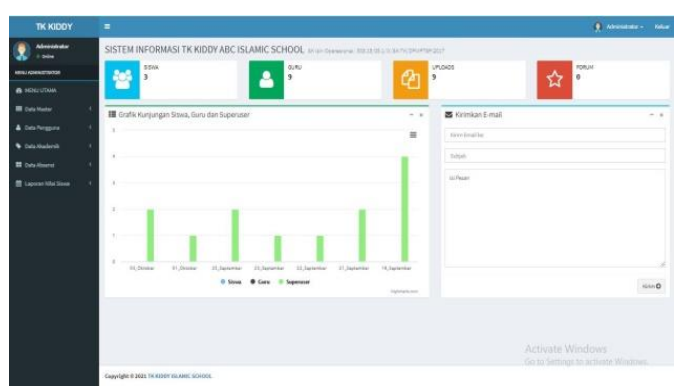

Gambar 4.1.2 Tampilan Menu Utama

\section{c. Tampilan Data Siswa}

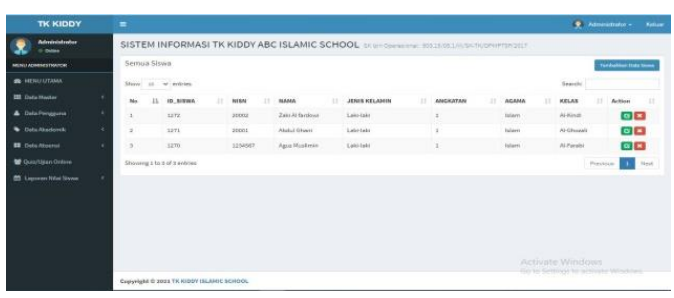

Gambar 4.1.3 Tampilan Data Siswa

\section{d. Tampilan Data Guru}

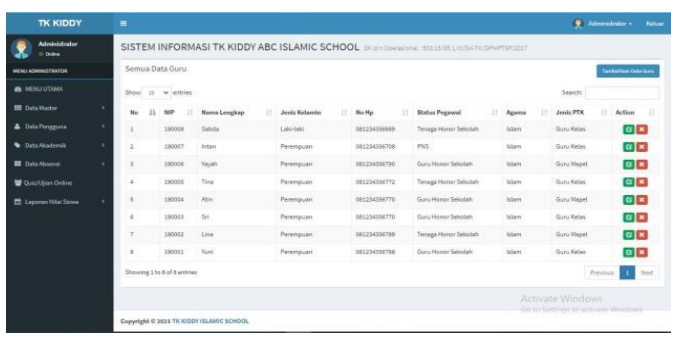

Gambar 4.1.4 Tampilan Data Guru

\section{e. Tampilan Data Nilai}

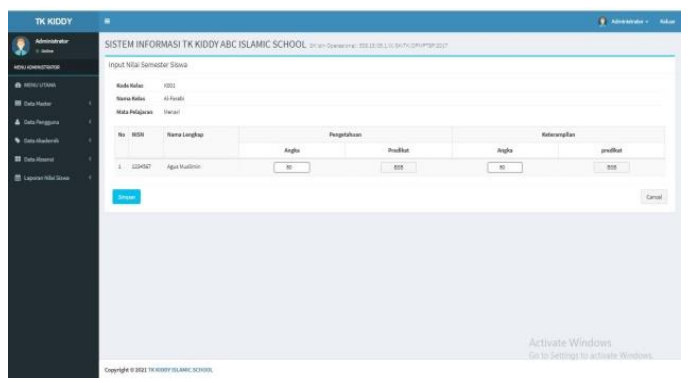

Gambar 4.1.5 Tampilan Data Nilai

\section{f. Tampilan Data Admin}

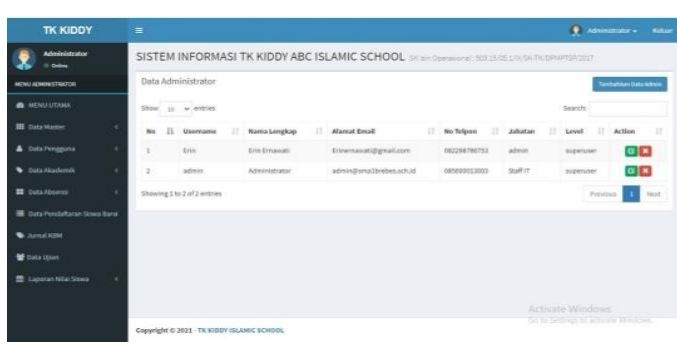

Gambar 4.1.6 Tampilan Admin

g. Tampilan Data Kelas

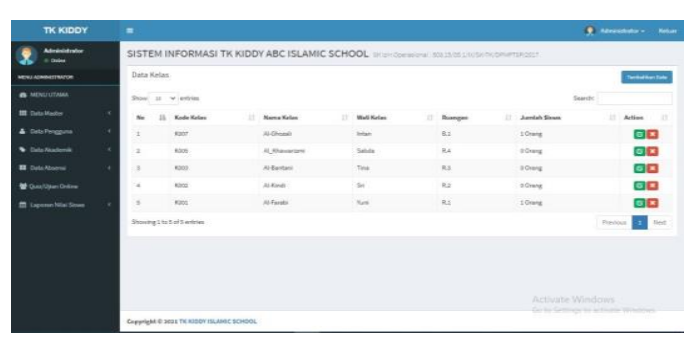

Gambar 4.1.7 Tampilan Data Kelas

\section{h. Tampilan Pelajaran}

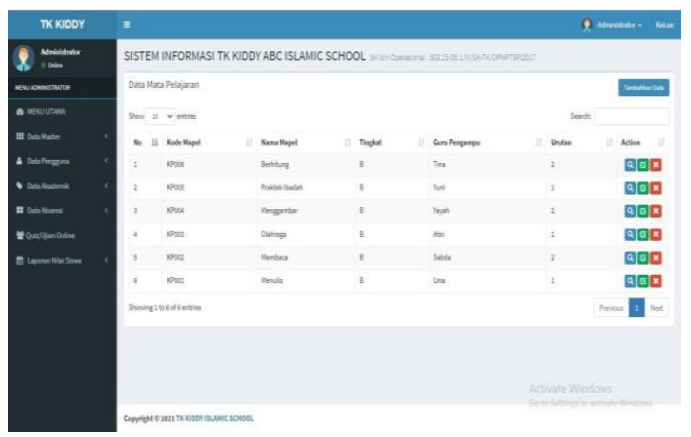

Gambar 4.1.8 Tampilan Data Pelajaran 


\section{i. Tampilan Input}

Pada tampilan input dikarenkan tampilan semua sama maka akan memberikan satu tampilan .

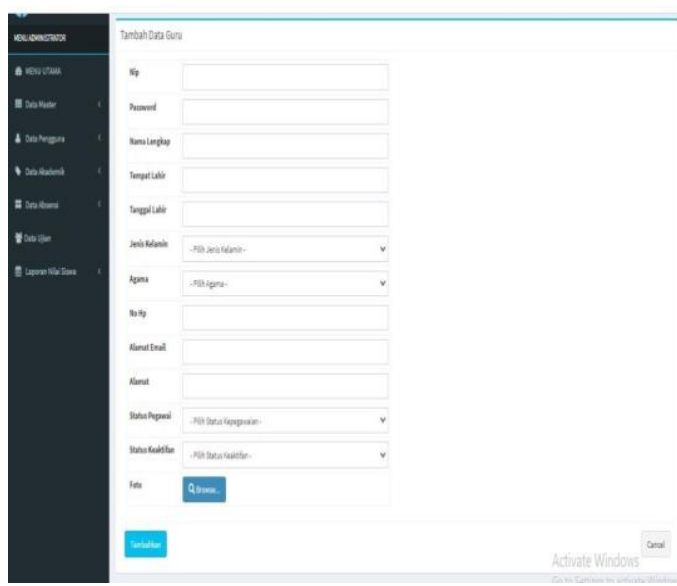

Gambar 4.1.9 Tampilan Input

\section{j. Tampilan Ubah}

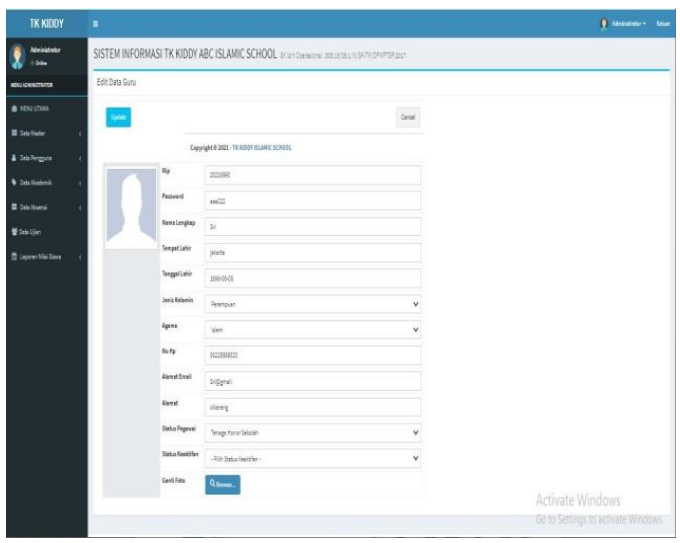

Gambar 4.10 Tampilan Ubah

\section{k. Tampilan Cari}

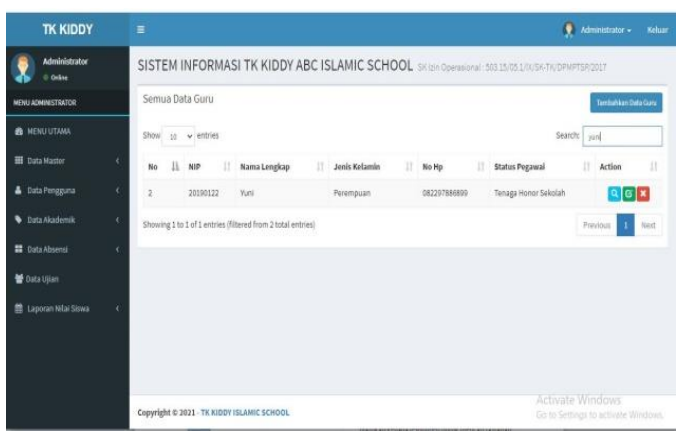

Gambar 4.11 Tampilan Cari
1. Tampilan Nilai Pada Raport Siswa

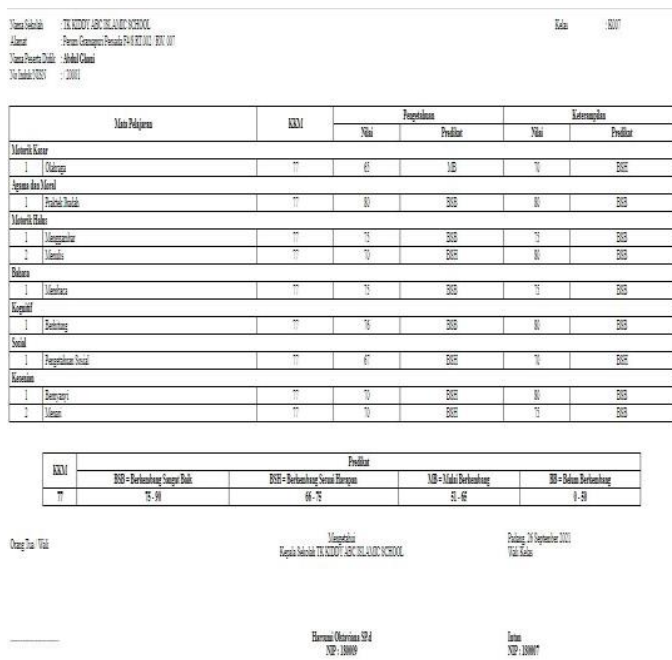

Gambar 4.12 Tampilan Nilai Pada Raport Siswa

\subsection{Pengolahan Data Nilai Siswa}

Pengolah data nilai siswa ini mengacu kepada kurikulum yang berlaku kepada sekolah TK dan PAUD yaitu berfokus kepada nilai-nilai perkembangan anak serta mengolah data nilai angka menjadi penjelasan perkembangan anak melalui penjelasan bahasa melalui tulisan. Dalam penilaian terhadap siswa-siswi TK KIDDY ABC ISLAMIC SCHOOL ialah :

\section{Agama dan Moral}

Agama dan moral yang di pelajari yaitu Mengenal Huruf Hijaiah,Berbagi Menghormati Sesama, Menghapal Surah dan Praktek Ibadah

\section{Motorik Kasar}

Motorik kasar yang dipelajari yaitu diantaranya ialah olah raga, kesehatan jasmani dan lainya.

\section{Motorik Halus}

Motorik halus yang dipelajari yaitu diantaranya ialah menulis, menggambar dan lainya yang berhubungan dengan motorik halus.

\section{Bahasa}

Bahasa yang dipelajari yaitu membaca memahami setiap kata dan lainya yang berhubungan dengan bahasa. 


\section{Kognitif}

Kognitif berfokus kepada logika yaitu diantaranya yaitu berhitung.

\section{Sosial}

Sosial yaitu tentang pengetahuan social seperti ramah tamah dan lainya.

\section{Kesenian}

Kesenian berhubungan dengan seni yaitu seperti menari bernyanyi.

Dari kesuluruhan penilaian terbagi 2 (dua) yaitu terhadap pengetahuan siswa dan keterampilan siswa.

Sistem penilaian dengan angka nilai dan dijabarkan dengan predikat berikut adalah nilai dan predikatnya :

Tabel 3.1 Penilaian

\begin{tabular}{|c|c|l|}
\hline Nilai & Predikat & \multicolumn{1}{|c|}{ Keterangan } \\
Angka & & Belum Berkembang \\
\hline $0-50$ & BB & Mulai Berkembang \\
\hline $51-65$ & MB & Sesuai \\
\hline $66-75$ & BSH & Barkembang \\
\hline $75-90$ & BSB & $\begin{array}{l}\text { Berkembang Sangat } \\
\text { Baik }\end{array}$ \\
\hline
\end{tabular}

\subsection{Validasi Pengujian Sistem}

Dalam pengujian kelayakan sistem ini penulis menggunakan tahapan uji kelayakan kuesioner. Kuesioner merupakan daftar pertanyaan yang diajukan kepada responden untuk mencari jawaban dari permasalahan yang teliti.

Berdasarkan batasan masalah, penerapan metode waterfall dalam pengembangan perncangan sistem informasi pengolahan nilai berbasis web dengan Keterangan

1. $\mathrm{SS}=$ sangat setuju $=4$

2. $S=$ setuju $=3$

3. $\mathrm{TS}=$ tidak setuju $=2$

4. $\mathrm{STS}=$ sangat tidak setuju $=1$
5. $\mathrm{Y}=$ Skor tertinggi likert $\mathrm{x}$ jumlah responden (Angka Tertinggi 4) "perhatikan bobot nilai"

$\mathrm{F} 6 \mathrm{X}=$ Skor terendah likert $\mathrm{x}$ jumlah responden (Angka terendah 1) "perhatikan bobot nilai"

Rumus index \% = total skor $/ \mathrm{Y} \times 100$.

Tabel 3.2 Kuesioner

\begin{tabular}{|c|c|c|c|c|c|}
\hline No & Pertanyaan & SS & $\mathrm{S}$ & $\mathrm{TS}$ & STS \\
\hline \multicolumn{6}{|c|}{ Tampilan : } \\
\hline 1 & $\begin{array}{l}\text { Sistem ini mudah } \\
\text { digunakan }\end{array}$ & 3 & 2 & & \\
\hline 2 & $\begin{array}{l}\text { Button sudah } \\
\text { bekerja sesuai } \\
\text { dengan } \\
\text { fungsinya }\end{array}$ & 4 & 4 & & \\
\hline 3 & $\begin{array}{l}\text { Keterangan } \\
\text { kegunaan menu } \\
\text { dalam sistem } \\
\text { sudah jelas dan } \\
\text { mudah bagi } \\
\text { pengguna }\end{array}$ & 3 & 2 & & \\
\hline 4 & $\begin{array}{l}\text { Pendataan dalam } \\
\text { sistem ini } \\
\text { berguna bagi } \\
\text { guru }\end{array}$ & 3 & 2 & & \\
\hline \multicolumn{6}{|c|}{ Kegunaan : } \\
\hline 1 & $\begin{array}{l}\text { Sistem ini dapat } \\
\text { membantu guru } \\
\text { dalam }\end{array}$ & 4 & 1 & & \\
\hline
\end{tabular}




\begin{tabular}{|l|l|l|l|l|l|}
\hline & pengolahan nilai & & & & \\
siswa & Sistem ini dapat & 4 & 1 & & \\
\hline 2 & bermanfaat untuk & & & & \\
\hline 3 & Dapat melakukan & 4 & 1 & & \\
proses tambah & & & & \\
\hline 4 & dan edit data & & & & \\
\hline & Dada menu melakukan & 3 & 2 & & \\
\hline
\end{tabular}

Tabel 3.3 Presentasi Keberhasilan

\begin{tabular}{|l|l|}
\hline Jawaban & Keterangan \\
\hline $0 \%-19.99 \%$ & $\begin{array}{l}\text { Sangat (Tidak Setuju, Buruk } \\
\text { atau Kurang Sekali) }\end{array}$ \\
\hline $20 \%-39.99 \%$ & $\begin{array}{l}\text { Tidak Setuju atau Kurang } \\
\text { Baik }\end{array}$ \\
\hline $40 \%-59.99 \%$ & Cukup atau Netral \\
\hline $60 \%-79.99 \%$ & Setuju, Baik, atau Suka \\
\hline $80 \%-100 \%$ & Sangat (Setuju, Baik, Suka) \\
\hline
\end{tabular}

Hasil perhitungan jawaban responden sebagai berikut :

1) Responden yang menjawab sangat setuju $(28)=28 \times 4=112$

2) Responden yang menjawab setuju (15) $=15 \times 3=45$

3) Responden yang menjawab tidak setuju (2) $=0 \times 2=0$
4) Responden yang menjawab tidak sangat setuju $(1)=0 \times 1=$ Total Skor $=$ $112+\quad 45+\quad 0+\quad 0=157$ Untuk mendapatkan hasil interpretasi, harus diketahui dulu skor tertinggi (X) dan angka terendah (Y) untuk item penilaian dengan rumus sebagai berikut $: \mathrm{Y}=$ Skor tertinggi likert $\mathrm{x}$ jumlah responden (Angka Tertinggi 28) "Perhatikan Bobot Nilai"X = Skor terendah likert $\mathrm{x}$ jumlah responden (Angka Terendah 15) "Perhatikan Bobot Nilai"Jumlah skor tertinggi untuk item SANGAT SETUJU ialah $28 \times 5=140$, sedangkan item SETUJU ialah 15 × $5=75$. Jadi, jika total skor responden di peroleh angka 140, maka penilaian interpretasi responden terhadap media pembelajaran tersebut adalah hasil nilai yang dihasilkan dengan menggunakan rumus Index $\%$.Rumus Index $\%=$ Total Skor $/ \mathrm{Y} \mathrm{x}$ 100Maka penyelesaian akhir dari contoh kasus :

$=$ Total Skor $/ \mathrm{Y}$ x 100

$=140 / 157 \times 100$

$=89,17 \%=89,2 \%$ Kategori Sangat (Setuju, Baik, Suka)

Dari hasil di atas maka dapat disimpulkan bahwa responden sangat (setuju,baik,suka) untuk perancangan sistem informasi pengolahan data nilai siswa berbasis web.

\section{KESIMPULAN}

Berdasarkan dari analisis yang penulis buat dengan sebenar-benarnya menghasilkan kesimpulan yaitu diantaranya.

1. Perancangan sistem informasi pengolahan data nilai menjadi lebih simple mudah dan rapi di bandingkan dengan pengolahan data sebelumnya sebelum adanya sistem tersebut.

2. Pendataan siswa dan para guru dapat disimpan dengan baik di dalam sistem yang terkoneksi dengan database.

3. Guru dapat memasukkan nilai langsung ke sistem serta raport tersedia pada sistem tersebut dan sistem input, update, delete data dalam bentuk pengoperasianya sangat mudah di fahami oleh pengguna sistem.

4. Metode waterfall sangat membantu dalam perancangan sistem yang telah dibuat. 


\section{DAFTAR PUSTAKA}

[1] Mulyani .(2017)." Metode Analisis dan Perancangan Sistem. Bandung: Abdi. Sistematika.

[2] Fauzi, Rizki Ahmad.2017.Sistem Informasi Akuntansi (Berbasis Akuntansi). Yogyakarta: Deepublish

[3] Andi, Kristanto. 2018. Perancangan Sistem Informasi dan Aplikasinya.Yogyakarta: Gava Media.

[4] Haerani, Reni dan Robiyanto.(2019). "sistem informasi pengolahan data nilai siswa berbasis web" Jurnal Sistem Informasi 6.2 (2019).

[5] Haerani, Reni dan Robiyanto.(2019). "sistem informasi pengolahan data nilai siswa berbasis web" Jurnal Sistem
Informasi 6.2 (2019).

[6] Wardana (2016). "Aplikasi Website PROFESIONAL dengan PHP dan JQuery", Jakarta: Elex Media Coputindo.

[7] Deval Gusrion. (2018) "SISTEM PEMBAYARAN SECARA CASHLESS PADA KOPERASI SEKOLAH YAYASAN IGASAR" Jurnal KomtekInfo Vol 5 No 2 (2018)

[8] Yudie Irawan.( 2017). "Sistem Informasi Perpustakaan Berbasis Web" jurnal jsinbis 5.1 (2017).

[9] Rosa dan Shalahuddin, M. (2018). "Rekayasa Perangkat Lunak Terstruktur dan Berorientasi Objek", Bandung: Informatika. 